\title{
Antioxidant compounds of organically and conventionally fertilized jambu (Acmella oleracea)
}

\section{Luciana da Silva Borges, Marizete Cavalcante de Souza Vieira, Fabio Vianello, Rumy Goto \& Giuseppina Pace Pereira Lima}

To cite this article: Luciana da Silva Borges, Marizete Cavalcante de Souza Vieira, Fabio Vianello, Rumy Goto \& Giuseppina Pace Pereira Lima (2016) Antioxidant compounds of organically and conventionally fertilized jambu (Acmella oleracea), Biological Agriculture \& Horticulture, 32:3, 149-158, DOI: $10.1080 / 01448765.2015 .1103304$

To link to this article: https://doi.org/10.1080/01448765.2015.1103304

册 Published online: 03 Nov 2015.

Submit your article to this journal

LII Article views: 187

View Crossmark data $₫$

Citing articles: 6 View citing articles $匚$ 


\title{
Antioxidant compounds of organically and conventionally fertilized jambu (Acmella oleracea)
}

\author{
Luciana da Silva Borges ${ }^{a}$, Marizete Cavalcante de Souza Vieirab ${ }^{b}$ Fabio Vianelloc, Rumy Gotod \\ and Giuseppina Pace Pereira Limab
}

\begin{abstract}
${ }^{a}$ Department of Horticulture, Universidade Federal Rural da Amazônia (UFRA), Campus Paragominas, Paragominas, Brazil; 'bepartment of Chemistry and Biochemistry, Institute of Biosciences, São Paulo State University (UNESP), Botucatu, Brazil; 'Department of Comparative Biomedicine and Food Science, University of Padua (UNIPD), Padova, Italy; ${ }^{\mathrm{d}}$ Faculdade de Ciências Agronômicas, Department of Horticulture, São Paulo State University (UNESP), Botucatu, Brazil
\end{abstract}

\begin{abstract}
Acmella oleracea (jambu), native to the Amazonas region (Brazil), has cosmetic and pharmacological properties, many of which are due to chemical components with antioxidant activity. Since organic cultivation has been reported to induce an increase in metabolic antioxidant components, this study aimed to determine the content of phenolic compounds, carotenoids, vitamin C, and polyamines, and the activity of peroxidase in two cultivars of jambu, Jambuarana, and Nazareth. Furthermore, leaves and inflorescences were studied to estimate the relative contribution of these tissues to the antioxidant potential of jambu. Organic farming induced higher levels of total phenolics and carotenoids in Jambuarana leaves and of spermidine and spermine in leaves and flowers of both the cultivars than conventional cultivation. Conventional fertilization led to nitrate accumulation in inflorescences and vitamin $\mathrm{C}$ in leaves, and to a higher total organic nitrogen content in jambu leaves and flowers than in organic cultivated plants. The fertilization procedures did not affect the activity of the enzyme peroxidase, but differences were observed between cultivars.
\end{abstract}

\section{ARTICLE HISTORY}

Received 4 June 2014

Accepted 30 September 2015

\section{KEYWORDS}

Peroxidase; phenolic compounds; pigments; polyamine

\section{Introduction}

Jambu (Acmella oleracea, syn. Spilanthes oleracea, Spilanthes acmella), native to the Amazonas region (Brazil), belongs to the Asteraceae family and grows in a tropical climate. Jambu contains about $0.7 \%$ of essential oil, which is used in the cosmetic and pharmaceutical industries for its pharmacological properties. These properties are due to the presence of chemical substances, among which trans-caryophyllene, germacrene D, L-dodecene, and spathulenol and spilanthol (Borges et al. 2012), can be found in flower and leaves. Chemical properties of this plant have aroused the interest of pharmaceutical and cosmetic companies, which use it as raw material for many products including a cosmetic cream to relax microtension of facial skin, preventing wrinkles and smoothing. Despite these innovations, this vegetable is not recorded in production reports and market estimates in Brazil and elsewhere. 
Studies show that $S$. acmella contains antioxidant compounds such as polyphenolic compounds and potent radical scavenging activity was observed in the 2,2-diphenylpicrylhydrazyl (DPPH) assay (Wongsawatkul et al. 2008; Prachayasittikul et al. 2009). Some research has been carried out with plants from conventional cultivation using fertilizers and agrochemicals and there are some reports that show that different morphological parts may contain different metabolite contents that contribute to radical scavenging activity (Siddhuraju et al. 2002).

In recent years, the demand for food and medicinal plants grown without agrochemicals and with higher levels of beneficial substances has grown worldwide and consumers have sought in organic agriculture the best source of this kind of product, even if the price is higher than that of conventional ones (Hoefkens et al. 2010). As a result, organic agriculture has expanded rapidly; globally, from 1999 to 2008, the total area of organic farming increased three times. In 2008, approximately 35 million hectares were under organic management worldwide (Willer and Lernoud 2013).

Several studies have shown that the mode of cultivation influences the content of compounds such as nitrate (Citak \& Sonmez 2010), which can range from 1 to $10,000 \mathrm{mg} \mathrm{kg}^{-1}$ (Ximenes et al. 2000), and antioxidants (Lima \& Vianello 2011). However, contradictory data have been presented (Hoefkens et al. 2010; Smith-Spangler et al. 2012). It is believed that, in the absence of pesticides, plants may contain higher levels of antioxidant compounds. This increased synthesis of phytochemicals is aimed at the defense against biotic and abiotic stresses. Evidence on the hypothesis that plant antioxidants can help to prevent or reduce the development of certain human diseases has been reported.

Phenolic compounds, ascorbic acid, and carotenoids, as well as a number of other substances with antioxidant activity, are among the best-known antioxidant compounds found in plants. It was hypothesized that biological effects of phenolic compounds are linked to specific cytotoxic events and to their ability to interact with enzymes via protein complexation. Furthermore, flavonoids act as scavengers of free radicals, such as reactive oxygen species (ROS), and also prevent ROS formation by chelation of transition metal ions (Pourcel et al. 2006). Among substances with antioxidant potential, polyamines were also related to many biological processes, including cell division and growth, morphogenesis and differentiation (Tiburcio et al. 1990). These substances may have a protective action on plants (Bouchereau et al. 1999) or they may promote negative effects through their oxidation by polyamine oxidases (Tiburcio et al. 1990), generating ROS such as hydrogen peroxide and aldehydes (Toumi et al. 2008), and alterations of peroxidase (EC 1.11.1.7) activity have been suggests as a protective role of the enzyme in system of ROS elimination and some studies show higher activity of this enzyme in plants grown in organic fertilization (Del Amor et al. 2008).

Thus, this study was conducted to evaluate whether the type of cultivation, organic or conventional, could modify the content of substances with antioxidant properties in two cultivars of jambu $(A$. oleracea) and, furthermore, to estimate the contribution of leaves and inflorescences to the antioxidant potential of jambu.

\section{Materials and methods}

\section{Cultivation}

The experiment was carried out in a greenhouse, built with an arched metal structure, $60 \mathrm{~m}$ long and $6 \mathrm{~m}$ wide with a $2 \mathrm{~m}$ in ceiling height. The metal structure was coated with a low-density polyethylene film, UV transparent, $0.1 \mathrm{~mm}$ thick. Geographic coordinates were: $22^{\circ} 44^{\prime} 50^{\prime \prime}$ South and $48^{\circ} 34^{\prime} 00^{\prime \prime}$ West at $765 \mathrm{~m}$ altitude. A drip irrigation system was adopted during the whole cycle, with dripper flow of $1.5 \mathrm{l} \mathrm{h}^{-1}$. The irrigation was performed twice a day, especially after transplantation, for the duration of 1-2 h. The farm and the greenhouse were certified for organic production (IBD - Biodynamic Institute, Botucatu, São Paulo, Brazil) and were converted to this crop management system more than 10 years before the start of this study.

The experimental design was randomized in blocks in a $2 \times 2$ factorial scheme with six repetitions, two fertilization procedures (organic and conventional) and two jambu cultivars (Jambuarana and Nazareth). 
Table 1. Characteristics of organic compost (cattle manure) and substrate used in the experiment.

\begin{tabular}{lccccccccc}
\hline & $\mathrm{N}$ & $\mathrm{P}_{2} \mathrm{O}_{5}$ & $\mathrm{~K}_{2} \mathrm{O}$ & Moisture & $\mathrm{OM}$ & $\mathrm{C}$ & $\mathrm{Ca}$ & $\mathrm{Mg}$ & $\mathrm{S}$ \\
\hline (\% DM) & & & & & & & & & \\
\hline Cattle manure & 1.47 & 1.54 & 1.38 & 14.30 & 41.00 & 22.80 & 1.20 & 0.40 & 0.30 \\
Substrate & 5.81 & 0.95 & 4.35 & 14.00 & 39.00 & 268 & 14.14 & 1.68 & 0.31 \\
& $\mathrm{Fe}$ & & $\mathrm{Cu}$ & $\mathrm{Mn}$ & $\mathrm{Na}$ & & $\mathrm{Zn}$ & $\mathrm{pH}$ & $\mathrm{C} / \mathrm{N}$ \\
(mg kg-1 DM) & & & & & & & & & \\
$\quad$ Cattle manure & 18650 & 200 & 364 & 2580 & & 386 & 7.80 & $16 / 1$ \\
Substrate & 19826 & 0.01 & 225 & 260 & & 76.4 & 6.2 & $46 / 1$ \\
\hline
\end{tabular}

Notes: $\mathrm{C}$ - organic carbon; OM - organic matter.

Table 2. Analysis of the soil before the experiment.

\begin{tabular}{|c|c|c|c|c|c|c|c|c|c|c|c|}
\hline $\mathrm{pH}$ & OM & Resin $P$ & $\mathrm{Al}^{3+}$ & $\mathrm{H}+\mathrm{Al}$ & $\mathrm{K}$ & $\mathrm{Ca}$ & $\mathrm{Mg}$ & SB & CEC & V & $S$ \\
\hline $\mathrm{CaCl}_{2}$ & $\left(\mathrm{~g} \mathrm{dm}^{-3}\right)$ & $\left(\mathrm{mg} \mathrm{dm}^{-3}\right)$ & \multicolumn{7}{|c|}{$\left(\mathrm{mmol}_{\mathrm{c}} \mathrm{dm}^{-3}\right)$} & $(\%)$ & $\left(\mathrm{mg} \mathrm{dm}^{-3}\right)$ \\
\hline $\begin{array}{l}5.3 \\
\text { Boron } \\
\left(\mathrm{mg} \mathrm{kg}^{-1} \mathrm{DM}\right)\end{array}$ & \multicolumn{2}{|c|}{ Copper } & \multicolumn{2}{|c|}{ Iron } & \multicolumn{3}{|c|}{ Manganese } & 19 & 35 & \multicolumn{2}{|r|}{ Zinc } \\
\hline 0.16 & 1.4 & & 40 & & & & & & & & 2.2 \\
\hline
\end{tabular}

Notes: $\mathrm{Ca}$ - calcium; $\mathrm{Mg}$ - magnesium; $\mathrm{Al}$ - aluminum; $\mathrm{H}+\mathrm{Al}$ - acidity potential; $\mathrm{SB}$ - sum of bases; CEC - cation exchange capacity (total CEC); $\mathrm{V}$ - saturation in bases; $\mathrm{OM}$ - organic matter; $\mathrm{S}$ - sulfur.

For organic production, $8 \mathrm{~kg} \mathrm{~m}^{-2}$ of cattle manure composted for 120 days (Table 1) was applied at planting and $1 \mathrm{~kg} \mathrm{~m}^{-2}$ manure was applied at 55, 70 and 80 days after transplanting jambu plants. For conventional production, ammonium nitrate $\left(120 \mathrm{~g} \mathrm{~m}^{-2}\right)$, single superphosphate $\left(200 \mathrm{~g} \mathrm{~m}^{-2}\right)$, and potassium chloride $\left(50 \mathrm{~g} \mathrm{~m}^{-2}\right)$ were used at planting and $50 \mathrm{~g} \mathrm{~m}^{-2}$ of NPK formulation (N:P:K 15:15:20) was applied at 55, 70, and 80 days after transplantation.

Seeds were sown in August 2012 in 128 compartment polystyrene trays containing substrate made with expanded vermiculite and organic materials of plant origin, free of pests, microorganisms, and weed seeds (Table 1), commonly used to grow organic seedlings in Brazil. Five jambu, cv. Jambuarana or Nazareth, seeds were placed in each compartment. Emergence occurred on the seventh day and seedlings were thinned to one per compartment. Seedlings were manually transplanted on the soil, 40 days after sowing, when they showed up to six leaves, into four plots $\left(6 \mathrm{~m}^{2}\right.$ each) with up to 18 plants per row and five rows per plot. The soil analysis at the start of this research is showed in Table 2. The spacing was $20 \times 25 \mathrm{~cm}$. The weeding was carried out every 10 days after the start of cultivation. In the initial period, the weeding was done with hoes. When the plants were more developed, manual weeding was done to avoid damaging the plants. No pests or diseases were observed during the experimental period. The average temperature was $21^{\circ} \mathrm{C}$.

The harvest was performed in the morning, 90 days after sowing, at the opening of the flower bud. Branches were cut at $7 \mathrm{~cm}$ from the soil. Jambu plants were washed, separated into leaves and inflorescences, frozen in liquid nitrogen, and kept at $-80^{\circ} \mathrm{C}$ for biochemical assays.

\section{Biochemical analysis}

The determination of ascorbic acid was carried out according to the Tillmans method, by titrimetry, based on the reduction of 2.6-dichlorophenol indophenol by ascorbic acid. Ascorbic acid was added to reaction vessel in which the oxidized indicator 2.6-dichlorophenol indophenol was present (Zenebon et al. 2008). The analysis of total phenolics was performed by spectrophotometry using the Folin-Ciocalteu reagent (Singleton \& Rossi 1965). The results were expressed in $\mathrm{mg}$ phenols $\mathrm{g}^{-1} \mathrm{dry}$ mass, as gallic acid equivalents. The extraction of flavonoids was performed according to the method of Popova et al. (2004) with minor adjustments. Fresh material was ground in liquid nitrogen, weighed and $10 \%(\mathrm{v} / \mathrm{v})$ acidified methanol was added. Subsequently, samples were treated in an ultrasonic 
bath for $30 \mathrm{~min}$ and $5 \%(\mathrm{w} / \mathrm{v})$ aluminum chloride was added. Samples were centrifuged for $20 \mathrm{~min}$ at $10,000 \times g$. The results were expressed in $\mathrm{mg}$ flavonoids $\mathrm{g}^{-1}$ fresh weight, as rutin equivalents. The extraction of pigments was performed on fresh samples according to the method described by Sims and Gamon (2002). Plant tissues were ground in liquid nitrogen and pulverized samples were weighed and homogenized in a mini-turrax (Marconi, Piracicaba, Brazil) in a chilled solution of acetone/0.2 M Tris-HCl (80:20, v/v), pH $7.8(3 \mathrm{ml})$ for $1 \mathrm{~min}$. The extraction was carried out in ice and protected from light. Then, samples were centrifuged at $2000 \times g$ for $5 \mathrm{~min}$ and supernatants were immediately read by spectrophotometry (Ultrospec 2000, Pharmacia Biotech, Centerville, USA) at 663 and $647 \mathrm{~nm}$ for chlorophylls, $537 \mathrm{~nm}$ for anthocyanins and $470 \mathrm{~nm}$ for carotenoids. The absorbance values were converted into $\mu \mathrm{g}$ total pigments $\mathrm{g}^{-1}$ fresh weight according to the equations:

$$
\begin{aligned}
& \text { Carotenoids }\left(\mu \mathrm{mol} \mathrm{ml} l^{-1}\right)=\left\{\mathrm{Abs}_{470 \mathrm{~nm}}\left[17.1 \times\left(\mathrm{Cl}_{\mathrm{a}}+\mathrm{Cl}_{\mathrm{b}}\right)-9.479 \times \text { anthocyanins }\right\} / 119.26\right. \\
& \text { Chlorophyll a }\left(\mu \mathrm{mol} \mathrm{ml} l^{-1}\right)=0.01373\left(\mathrm{Abs}_{663 \mathrm{~nm}}\right)-0.000897\left(\mathrm{Abs}_{537 \mathrm{~nm}}\right)-0.003046\left(\mathrm{Abs}_{647 \mathrm{~nm}}\right) \\
& \text { Chlorophyll b }\left(\mu \mathrm{mol} \mathrm{m} l^{-1}\right)=0.02405\left(\mathrm{Abs}_{647 \mathrm{~nm}}\right)-0.004305\left(\mathrm{Abs}_{537 \mathrm{~nm}}\right)-0.005507\left(\mathrm{Abs}_{663 \mathrm{~nm}}\right)
\end{aligned}
$$

The antioxidant activity was determined according to the methodology reported by Brand-Williams et al. (1995). DPPH solution was prepared by dissolving $10 \mathrm{mg}$ of DPPH in $50 \mathrm{ml}$ of $99.8 \%$ ethanol. Samples (1.0 g), previously ground in liquid nitrogen, were weighed and centrifuged (Hettich Zentrifugen Mikro 220R, DJB Labcare, Newport Pagnell, UK) at $2000 \times g$ in $99.8 \%$ ethanol (10 ml) for $10 \mathrm{~min}$ at $5{ }^{\circ} \mathrm{C}$. Supernatant aliquots $(0.5 \mathrm{ml})$ were combined with ethanol $(3 \mathrm{ml})$, and DPPH solution $(300 \mu \mathrm{l})$ was added. The test tubes were stored in the dark for $60 \mathrm{~min}$. A negative control was prepared with $0.3 \mathrm{mM} \mathrm{DPPH}$ in ethanol to check the decay of the radical donor in our experimental conditions. Readings were carried out at $517 \mathrm{~nm}$, and converted into percentage of antioxidant activity by the following relationship: \% reduced $\mathrm{DPPH}=[($ Abs control - Abs sample $) / A b s$ control $] \times 100$. A calibration curve was obtained with $20,40,80,120$, and $160 \mu \mathrm{mol}$ Trolox and the results were expressed as $\mu \mathrm{M}$ Trolox equivalents $\mathrm{g}^{-1}$ sample (TEAC).

The polyamine content was determined according to method described by Lima et al. (2009). Polyamines were quantified, by comparison with standards, by fluorescence emission spectroscopy (excitation at $350 \mathrm{~nm}$ and emission at $495 \mathrm{~nm}$ ) by a Video Documentation System (Amersham Pharmacia Biotech, Inc., San Francisco, CA, USA), using the Image Master software, version 2.0, San Francisco, USA. The content of free polyamines was expressed as $\mu \mathrm{g} \mathrm{g}^{-1}$ fresh weight. Nitrate content was determined by a compact ion meter (C-141 Horiba, Kyoto, Japan) and the results were expressed as $\mathrm{mg} \mathrm{kg}^{-1}$. Dried and ground samples $(100 \mathrm{mg})$ were used for the determination of total organic nitrogen content (N) according to AOAC (1995). Samples, previously powdered in liquid nitrogen, were analyzed for peroxidase (EC 1.11.1.7) activity according to the method described by Lima et al. (1999). Aminoantipyrine and phenol were used for the determination of enzyme catalytic activity on hydrogen peroxide and the results were expressed as $\mu \mathrm{mol} \mathrm{H}_{2} \mathrm{O}_{2}$ decomposed $\mathrm{g}^{-1} \mathrm{~min}^{-1}$.

\section{Statistical analysis}

All data were statistically analyzed by analysis of variance (ANOVA) and Tukey's least significant difference test was used to compare means at the 0.01 probability level. The analyses were performed by the SISVAR software (UFLA, Lavras, Brazil).

\section{Results and discussion}

Organic farming does not use chemical fertilizers such as urea or ammonium nitrate. The present results showed that jambu leaves of both cultivars (Jambuarana and Nazareth) had higher values of antioxidant activity and vitamin $\mathrm{C}$ concentration under conventional than under organic fertilization (Table 3). According to Lee and Kader (2000), the application of nitrogen fertilizers tends to 
Table 3. Vitamin C, antioxidant activity (TEAC), nitrate and organic nitrogen concentration in leaves, and inflorescences of jambu cvs. Jambuarana and Nazareth under organic and mineral fertilization.

\begin{tabular}{|c|c|c|c|c|c|c|c|c|}
\hline & \multicolumn{4}{|c|}{ Leaves } & \multicolumn{4}{|c|}{ Inflorescences } \\
\hline & $\begin{array}{l}\text { Vitamin } \\
\mathrm{C}\left(\mathrm{mg}^{-1}\right. \\
\left.100 \mathrm{~g}^{-1}\right)\end{array}$ & $\begin{array}{c}\text { TEAC (mg } \\
\left.100 \mathrm{~g}^{-1}\right)\end{array}$ & $\begin{array}{c}\text { Nitrate } \\
(\mathrm{mg} \\
\left.100 \mathrm{~g}^{-1}\right)\end{array}$ & $\begin{array}{c}\mathrm{N}(\mathrm{mg} \\
\left.100 \mathrm{~g}^{-1}\right)\end{array}$ & $\begin{array}{c}\text { Vitamin } \\
\mathrm{C}(\mathrm{mg} \\
\left.100 \mathrm{~g}^{-1}\right)\end{array}$ & $\begin{array}{c}\text { TEAC (mg } \\
\left.100 \mathrm{~g}^{-1}\right)\end{array}$ & $\begin{array}{c}\text { Nitrate } \\
(\mathrm{mg} \\
\left.100 \mathrm{~g}^{-1}\right)\end{array}$ & $\begin{array}{c}\mathrm{N}(\mathrm{mg} \\
\left.100 \mathrm{~g}^{-1}\right)\end{array}$ \\
\hline \multicolumn{9}{|c|}{ Organic fertilization } \\
\hline Jambuarana & $3.21 \mathrm{bA}^{*}$ & $0.20 \mathrm{bA}$ & $1567 \mathrm{aB}$ & $0.29 \mathrm{bA}$ & $9.62 \mathrm{aA}$ & $0.20 \mathrm{aA}$ & $1525 \mathrm{bB}$ & $0.23 \mathrm{bB}$ \\
\hline Nazareth & $3.09 \mathrm{bA}$ & $0.20 \mathrm{bA}$ & $2100 \mathrm{aA}$ & $0.25 \mathrm{bB}$ & $10.83 \mathrm{aA}$ & $0.20 \mathrm{aA}$ & $1950 \mathrm{bA}$ & $0.29 \mathrm{bA}$ \\
\hline \multicolumn{9}{|c|}{ Mineral fertilization } \\
\hline Jambuarana & $19.96 \mathrm{aA}$ & $0.40 \mathrm{aA}$ & $1733 \mathrm{aA}$ & $0.59 \mathrm{aA}$ & $9.45 \mathrm{aA}$ & $0.20 \mathrm{aA}$ & $1725 \mathrm{aB}$ & $0.53 \mathrm{aB}$ \\
\hline Nazareth & $15.95 \mathrm{aB}$ & $0.31 \mathrm{aB}$ & $1833 \mathrm{aA}$ & $0.32 \mathrm{aB}$ & $8.33 \mathrm{bB}$ & $0.16 \mathrm{bB}$ & $2100 \mathrm{aA}$ & $0.61 \mathrm{aA}$ \\
\hline Cultivar (C) & ** & $* *$ & ns & ** & ** & $* *$ & ** & ** \\
\hline $\begin{array}{l}\text { Fertilization } \\
\text { (F) }\end{array}$ & $* *$ & $* *$ & ns & $* *$ & $* *$ & $* *$ & $* *$ & $* *$ \\
\hline$(\mathrm{C} \times \mathrm{F})$ & $* *$ & $* *$ & ns & $* *$ & ns & $* *$ & ns & ns \\
\hline CV (\%) & 5.24 & 5.39 & 10.30 & 4.92 & 12.86 & 3.29 & 4.47 & 6.23 \\
\hline
\end{tabular}

"Lower-case letters compare means between fertilization procedures for each cultivar. Upper-case letters compare means between cultivars within each fertilization procedure. Means followed by the same letter do not differ significantly by Tukey test at $1 \%$ probability, $\mathrm{n}=6$. $\mathrm{ns}$ : not significant.

** Signicant by Tukey test at $1 \%$ probability.

Table 4. Total phenol, flavonoid, and carotenoid concentrations in leaves and inflorescences of jambu cvs. Jambuarana and Nazareth under organic and mineral fertilization.

\begin{tabular}{|c|c|c|c|c|c|c|}
\hline & \multicolumn{3}{|c|}{ Leaves } & \multicolumn{3}{|c|}{ Inflorescences } \\
\hline & $\begin{array}{c}\text { Phenol (mg } \\
\left.100 \mathrm{~g}^{-1}\right)\end{array}$ & 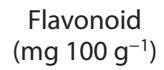 & 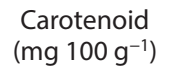 & $\begin{array}{c}\text { Phenol (mg } \\
\left.100 \mathrm{~g}^{-1}\right)\end{array}$ & 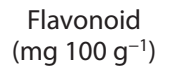 & 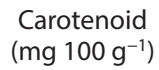 \\
\hline \multicolumn{7}{|c|}{ Organic fertilization } \\
\hline $\begin{array}{l}\text { Jambuarana } \\
\text { Nazareth }\end{array}$ & $\begin{array}{c}588.65 \mathrm{aA}^{*} \\
559.96 \mathrm{aA}\end{array}$ & $\begin{array}{l}9.32 \mathrm{aA} \\
8.79 \mathrm{aA}\end{array}$ & $\begin{array}{l}53.61 \mathrm{aA} \\
49.82 \mathrm{aA}\end{array}$ & $\begin{array}{l}292.81 \mathrm{aA} \\
303.95 \mathrm{aA}\end{array}$ & $\begin{array}{l}4.10 \mathrm{aA} \\
3.87 \mathrm{aA}\end{array}$ & $\begin{array}{l}424.77 \mathrm{aA} \\
379.69 \mathrm{aA}\end{array}$ \\
\hline \multicolumn{7}{|c|}{ Mineral fertilization } \\
\hline $\begin{array}{l}\text { Jambuarana } \\
\text { Nazareth }\end{array}$ & $\begin{array}{l}508.95 \mathrm{bA} \\
439.95 \mathrm{bB}\end{array}$ & $\begin{array}{l}9.55 \mathrm{aA} \\
6.09 \mathrm{bB}\end{array}$ & $\begin{array}{l}37.89 \mathrm{bA} \\
36.41 \mathrm{bA}\end{array}$ & $\begin{array}{l}307.59 \mathrm{aA} \\
271.50 \mathrm{aB}\end{array}$ & $\begin{array}{l}4.17 \mathrm{aA} \\
3.80 \mathrm{aA}\end{array}$ & $\begin{array}{l}255.11 \mathrm{bA} \\
252.67 \mathrm{bA}\end{array}$ \\
\hline Cultivar (C) & $* *$ & $* *$ & ns & $* *$ & ns & ns \\
\hline Fertilization (F) & ** & $* *$ & ** & ns & ns & ** \\
\hline$(\mathrm{C} \times \mathrm{F})$ & $* *$ & $* *$ & ns & ns & ns & ns \\
\hline CV (\%) & 6.98 & 6.39 & 10.32 & 6.91 & 8.59 & 9.44 \\
\hline
\end{tabular}

*Lower-case letters compare means between fertilization procedures for each cultivar. Upper-case letters compare means between cultivars within each fertilization procedure. Means followed by the same letter do not differ significantly by Tukey test at $1 \%$ probability, $\mathrm{n}=6$. $\mathrm{ns}$ : not significant.

** Signicant by Tukey test at $1 \%$ probability.

reduce the level of ascorbic acid in most vegetables. This differs from the findings of the present work, demonstrating that the application of nitrogen at a proper dose can promote an increase in vitamin $\mathrm{C}$ concentration and that there may be a positive correlation between vitamin $\mathrm{C}$ and nitrogen supply (Muller \& Hippe 1987). Higher vitamin C content in conventionally cultivated vegetables than in organic ones has also been reported by Hakala et al. (2003). In the present study, inflorescences of cv. Nazareth, under mineral fertilization, contained lower vitamin $\mathrm{C}$ and antioxidant activity than those of organically cultivated plants. In a review comparing organic and conventional farming, SmithSpangler et al. (2012) claimed that there is no difference in the content of vitamin C in organic and conventional vegetables, differing from the present and many other results. Of course, many factors can influence the content of vitamin $\mathrm{C}$ including growing conditions, growing locations and cultivars, and the findings cannot be generalized (Lee \& Kader 2000). Vitamin C levels found in jambu were lower than in other vegetables, such as spinach, grown under either conventional or organic fertilization (Citak \& Sonmez 2010). 
Table 5. Polyamine concentration in jambu cultivars (Jambuarana and Nazareth) under organic and mineral fertilization.

\begin{tabular}{|c|c|c|c|c|c|c|}
\hline \multirow[b]{3}{*}{ Cultivars } & \multicolumn{6}{|c|}{ Polyamine concentration ( $\mu \mathrm{g} \mathrm{g}^{-1} \mathrm{FW}$ ) } \\
\hline & \multicolumn{3}{|c|}{ Leaves } & \multicolumn{3}{|c|}{ Inflorescences } \\
\hline & PUT & SPD & SPM & PUT & SPD & SPM \\
\hline \multicolumn{7}{|c|}{ Organic fertilization } \\
\hline $\begin{array}{l}\text { Jambuarana } \\
\text { Nazareth }\end{array}$ & $\begin{array}{l}1.71 \mathrm{aA}^{*} \\
1.18 \mathrm{aB}\end{array}$ & $\begin{array}{l}0.77 \mathrm{aB} \\
1.25 \mathrm{aA}\end{array}$ & $\begin{array}{l}1.82 \mathrm{aB} \\
4.05 \mathrm{aA}\end{array}$ & $\begin{array}{l}1.20 \mathrm{aA} \\
1.27 \mathrm{aA}\end{array}$ & $\begin{array}{l}0.56 \mathrm{aB} \\
1.01 \mathrm{aA}\end{array}$ & $\begin{array}{l}1.33 \mathrm{aB} \\
2.08 \mathrm{aA}\end{array}$ \\
\hline \multicolumn{7}{|c|}{ Mineral fertilization } \\
\hline $\begin{array}{l}\text { Jambuarana } \\
\text { Nazareth } \\
\text { Cultivar (C) } \\
\text { Fertilization (F) } \\
(\mathrm{C} \times \mathrm{F}) \\
\text { CV (\%) }\end{array}$ & $\begin{array}{c}1.28 \mathrm{bA} \\
1.24 \mathrm{aA} \\
* * \\
* * \\
* * \\
8.84\end{array}$ & $\begin{array}{c}0.62 \mathrm{aA} \\
0.94 \mathrm{bA} \\
\mathrm{ns} \\
* * \\
* * \\
13.22\end{array}$ & $\begin{array}{c}0.80 \mathrm{bA} \\
1.36 \mathrm{bA} \\
* * \\
* * \\
* * \\
10.39\end{array}$ & $\begin{array}{c}1.21 \mathrm{aA} \\
1.23 \mathrm{aA} \\
\mathrm{ns} \\
\mathrm{ns} \\
\mathrm{ns} \\
4.13\end{array}$ & $\begin{array}{c}0.30 \mathrm{bB} \\
0.89 \mathrm{bA} \\
* * \\
* * \\
* * \\
10.79\end{array}$ & $\begin{array}{c}0.99 \mathrm{bB} \\
1.53 \mathrm{bA} \\
\mathrm{ns} \\
* * \\
* * \\
6.26\end{array}$ \\
\hline
\end{tabular}

Notes: PUT - putrecine, SPD - spermidine, SPM - spermine.

*Lower-case letters compare means between fertilization procedures for each cultivar. Capital letters compare means between cultivars within each fertilization procedure. Means followed by the same letter do not differ significantly by Tukey test at $1 \%$ probability, $\mathrm{n}=6$. $\mathrm{ns}$ : not significant.

** Signicant by Tukey test at $1 \%$ probability.

Table 6. Peroxidase activity (POD) in leaves and inflorescences of jambu cvs. Jambuarana and Nazareth under organic and mineral fertilizations.

\begin{tabular}{lcc}
\hline & $\mathrm{POD}\left(\mu \mathrm{mol} \mathrm{H}_{2} \mathrm{O}_{2}\right.$ decomposed $\left.\mathrm{g}^{-1} \mathrm{~min}^{-1}\right)$ \\
\cline { 2 - 3 } Cultivars & Leaves & Inflorescence \\
\hline Organic fertilization & & $0.07 \mathrm{aB}$ \\
Jambuarana & $0.14 \mathrm{aA}$ & $0.09 \mathrm{aA}$ \\
Nazareth & $0.09 \mathrm{aB}$ & $0.08 \mathrm{aA}$ \\
Mineral fertilization & & $0.09 \mathrm{aA}$ \\
Jambuarana & $0.15 \mathrm{aA}$ & $* *$ \\
Nazareth & $0.10 \mathrm{aB}$ & $* *$ \\
Cultivar (C) & $* *$ & $* *$ \\
Fertilization (F) & $\mathrm{ns}$ & 12.80 \\
(C $\times$ F) & $\mathrm{ns}$ & \\
CV (\%) & 5.61 & \\
\hline
\end{tabular}

*Lower-case letters compare means between fertilization procedures for each cultivar. Capital letters compare means between cultivars within each fertilization procedure. Means followed by the same letter do not differ significantly by Tukey test at $1 \%$ probability, $n=6$.

In the present study, nitrate content in leaves showed significant effect of cultivar when cultivated with organic fertilization, different from that found when the cultivars grown with conventional fertilizer. $\mathrm{N}$ content had higher values in both cultivars under mineral fertilization (Table 3 ). This higher $\mathrm{N}$ level found can be attributed to the $\mathrm{N}$ content in the mineral fertilization, as described in other studies (Herencia et al. 2011). Inflorescences of organically cultivated Jambuarana and Nazareth had lower nitrate content than with mineral fertilization, as was found for the nitrogen concentration (Table 3). High levels of nitrate have been described in plants grown under mineral fertilization (Winter \& Davis 2006) and, generally, fertilizers are used throughout the whole crop cycle, thus promoting an increase in the content of certain elements.

The consumption of vegetables with high levels of vitamin $\mathrm{C}$ and low nitrate content is of interest in the promotion of human health. Vitamin $\mathrm{C}$ acts in processes involving gene expression and as a cofactor of several enzymes, catalyzing the formation of nitric oxide (NO) from organic nitrogen derivatives. A preventive potential was attributed to this vitamin in the development of nitrate tolerance. Nitrate derived from consumed vegetables may be converted to nitrite, nitric oxide, and other secondary products, possibly exerting protective effects on the cardiovascular system (Lundberg et al. 2006). 
Organic fertilization induced higher levels of phenols in jambu leaves than mineral fertilization (Table 4). Difference in the level of phenols was observed in inflorescences in relation to the fertilization. Organic fertilization induced higher phenols content in both cultivars when compared with conventional fertilization. This difference was not observed in inflorescences. Both leaves and inflorescences from cv. Nazareth showed lower values than cv. Jambuarana under mineral fertilization but not under organic fertilization. Some studies showed that organic cultivation induces higher phenolic content compared with conventional fertilization (Lima \& Vianello 2011). However, this did not occur in this study with the inflorescences. The differences between the types of the fertilization on the phenol content can be observed only when considering the leaves of both cultivars of jambu.

No significant differences were observed in inflorescences regarding total flavonoid content (Table 4), whereas in cv. Nazareth leaves grown under organic fertilization, a higher level of these compounds was observed with mineral fertilization. The content of these substances is recognized for their protective action on human health. Many authors have claimed that organic farming may influence the levels of some antioxidants, mainly phenolic compounds and flavonoids (Faller \& Fialho 2009). However, in the present work, the comparison of flavonoid content in leaves and inflorescences of the two jambu cultivars did not corroborate this hypothesis.

A higher level of total carotenoids was detected in leaves and inflorescences (Table 4) of organic jambu than in conventional plants. Probably, this effect can be attributed to the different fertilization practices. Controversial reports can be found in the literature; some studies showed that an increase in nitrogen content affects carotenoid concentration in thyme (Thymus vulgaris) (Baranauskienne et al. 2003), a herb used for essential oil production. Carotenoids are associated with chloroplasts and their action, as energy carriers or as antioxidant molecules, can be influenced by fertilization. It was reported that the cultivation method may interfere with plant carotenoid content (Reif et al. 2012) and a promoting effect of organic fertilization on chlorophyll and carotenoid content can be attributed to the fact that nitrogen is a constituent of chlorophyll molecules. Moreover, nitrogen is a constituent of amino acids and proteins, which, coupled with lipids, act as structural compounds of chloroplasts. Nevertheless, carotenoid content in plants can widely vary, due to plant variety, growing conditions, climate, and age (Baranauskienne et al. 2003).

Polyamine content was affected by the cultivation practice. Jambu (Jambuarana and Nazareth cultivars), when grown under organic fertilization, showed higher spermine content in leaves, and spermine and spermidine contents in inflorescences than with mineral fertilization (Table 5). Leaves of $\mathrm{cv}$. Jambuarana cultivated with mineral fertilization contained lower putrescine level than with organic fertilization, although cv. Nazareth did not show this difference. Leaves of cv. Nazareth had a low level of spermidine under mineral cultivation. There was no difference between cultivars when grown with mineral fertilization; however, when grown with organic manure, cv. Nazareth leaves contained higher spermidine content than cv. Jambuarana. Inflorescences of Jambuarana and Nazareth not show significant differences of putrescine content between or types of fertilization studied. The spermidine and spermine contents in cv. Jambuarana were higher than cv. Nazareth with both organic and mineral fertilization.

It is believed that polyamines act on cells by stimulating proliferation and differentiation. Additionally, they act as antioxidants (Lima \& Vianello 2011). Therefore, the ratio putrescine/(spermine + spermidine) is generally correlated with cell elongation because, according to the literature, transformation of putrescine to spermidine and finally to spermine is important in the control of cell division (Galston \& Kaur-Sawhney 1995). Thus, a high putrescine/(spermine + spermidine) ratio indicates a lower cell growth and, therefore, jambu produced under organic farming should tend to show higher productivity. In the present study, taking into account fertilization procedures and cultivars, this relationship cannot be considered as valid. The productivity did not show significant differences between the production methods; 2.61 and $2.98 \mathrm{~kg} \mathrm{~m}^{-2}$ were found for organic and conventional Jambuarana leaves, respectively. The same was observed for inflorescences; $1.03 \mathrm{~kg} \mathrm{~m}^{-2}$ under organic and $1.01 \mathrm{~kg} \mathrm{~m}^{-2}$ under conventional fertilization. Only leaves from Nazareth cultivar showed a higher productivity $\left(2.96 \mathrm{~kg} \mathrm{~m}^{-2}\right)$ under conventional than under organic $\left(1.31 \mathrm{~kg} \mathrm{~m}^{-2}\right)$ cultivation. 
However, in this cultivar, no significant production differences were observed between conventional $\left(0.77 \mathrm{~kg} \mathrm{~m}^{-2}\right)$ and organic $\left(0.72 \mathrm{~kg} \mathrm{~m}^{-2}\right)$ inflorescences.

Several studies have reported that the reduction of plant putrescine/(spermine + spermidine) ratio could be related to an increased protection against adverse conditions (Bouchereau et al. 1999). Other reports suggested that the accumulation of putrescine could cause negative effects on plant development, including loss of proteins, membrane depolarization, and necrosis (Tiburcio et al. 1990). This negative effect on plant growth can be explained by the activity of enzymes, amine or diamine oxidases, which oxidize polyamines, inducing the formation of ROS, which will damage cell membranes (Toumi et al. 2008). ROS include hydrogen peroxide, a substrate of the enzyme peroxidase.

Organic fertilization usually induces an increased level of antioxidant compounds, which can protect plants against the ROS generated during metabolism (Lima \& Vianello 2011). Thus, the peroxidase activity in organic cultivated plants would be expected to differ from that measured in mineral cultivated ones. In jambu leaves, peroxidase activity did not show significant variations between fertilization procedures, but differences were observed between cultivars (Table 6). No significant differences were observed in inflorescences from Nazareth cultivar between the two cultivation procedures, but when these plants were cultivated under organic fertilization showed higher peroxidase activity than Jambuarana. In the present study, peroxidase activity in leaves differed only between the two cultivars, i.e. POD activity was higher in leaves of Jambuarana. This could be related to other data, such as the levels of phenolic compounds, carotenoids, and vitamin C, which form the overall antioxidant protection system, leading to the suggestion of a greater resistance of Jambuarana than of Nazareth to environmental adverse factors. Other studies also related the activity of oxidative enzymes, such as peroxidases, to the interruption of the cascade of events during the oxidation and detoxification processes by ROS in cells (Lee et al. 2007). However, generally, the content of an antioxidant enzyme does not provide sufficient protection against the damages promoted by oxidative stress.

\section{Conclusions}

Jambu is widely used as a medicinal plant, especially in the cosmetics industry. Currently, the industries of this area have sought to develop organic farming which produces agrochemical-free, non-genetically modified products, which often contain higher levels of bioactive compounds than those from conventional farming. In the present research, the organic cultivation of the jambu induced positive changes in levels of various phytochemicals. Thus, the increase in some phytochemicals would be a positive response, improving the defense system of plants against pests or diseases, even if they have not shown any symptoms. In this study, differences in types and amounts of some phytochemicals between two varieties were found, including different levels of compounds with antioxidant potential. Organic farming induced higher levels of some phytochemicals, such as total phenolics and carotenoids in cv. Jambuarana leaves. However, spermidine and spermine in leaves and inflorescences of both the cultivars analyzed (Jambuarana and Nazareth) showed higher contents than the conventional mineral fertilization. Thus, the choice of the cultivar of jambu, and whether to use organic or conventional fertilization must based on the target bioactive compounds.

\section{Disclosure statement}

No potential conflict of interest was reported by the authors.

\section{Funding}

This work was supported by the Doctoral Program in the Country with Internship Abroad (ESDP)/Coordination for the Improvement of Higher Level -or Education- Personnel (CAPES) [grant number 0081-11-6], for the scholarship (PhD) to the first author; National Council for Scientific and Technological Development (CNPq) [grant number 306151/2012-0]. 


\section{References}

AOAC. 1995. Official methods of analysis. 16th ed. Arlington (VA): Association of Official Analytical Chemists.

Baranauskienė R, Venskutonis PR, Viškelis P, Dambrauskiené E. 2003. Influence of nitrogen fertilizers on the yield and composition of thyme (Thymus vulgaris). J Agric Food Chem. 51:7751-7758.

Borges LS, Vianello F, Marques MOM, Lima GPP. 2012. Influence of organic and mineral soil fertilization and essential oil of Spilanthes oleracea. Am J Plant Physiol. 7:135-142.

Bouchereau A, Aziz A, Larher F, Martin-Tanguy J. 1999. Polyamines and environmental challenges: recent development. Plant Sci. 140:103-125.

Brand-Williams W, Cuvelier ME, Berset C. 1995. Use of a free radical method to evaluate antioxidant activity. LWT Food Sci Technol. 28:25-30.

Citak S, Sonmez S. 2010. Influence of organic and conventional growing conditions on the nutrient contents of white head cabbage (Brassica oleracea var. capitata) during two successive seasons. J Agric Food Chem. 58:1788-1793.

Del Amor FM, Serrano-Martínez A, Fortea I, Núñez-Delicado E. 2008. Differential effect of organic cultivation on the levels of phenolics, peroxidase and capsidiol in sweet peppers. J Agric Food Chem. 88:770-777.

Faller ALK, Fialho E. 2009. The antioxidant capacity and polyphenol content of organic and conventional retail vegetables after domestic cooking. Food Res Int. 42:210-215.

Galston AW, Kaur-Sawhney R.1995. Polyamines as endogenous growth regulators. In: Davies PJ, editor. Plant hormones, physiology, biochemistry and molecular biology. 2nd ed. Dordrecht: Kluwer Academic; p. 158-178.

Hakala M, Lapveteläinen A, Huopalahti R, Kallio H, Tahvonen R. 2003. Effects of varieties and cultivation conditions on the composition of strawberries. J Food Compos Anal. 16:67-80.

Herencia J, García-Galavís PA, Dorado JAR, Maqueda C. 2011. Comparison of nutritional quality of the crops grown in an organic and conventional fertilized soil. Sci Hortic. 129:882-888.

Hoefkens C, Sioen I, Baert K, De Meulenaer B, De Henauw S, Vandekinderen I, Devlieghere F, Opsomer A, Verbeke W, Camp VJ. 2010. Consuming organic versus conventional vegetables: The effect on nutrient and contaminant intakes. Food Chem Toxicol. 48:3058-3066.

Lee S-H, Ahsan N, Lee K-W, Kim D-H, Lee D-G, Kwak S-S, Kwon S-Y, Kim T-H, Lee B-H. 2007. Simultaneous overexpression of both CuZn superoxide dismutase and ascorbate peroxidase in transgenic tall fescue plants confers increased tolerance to a wide range of abiotic stresses. J Plant Physiol. 164:1626-1638.

Lee SK, Kader AA. 2000. Preharvest and postharvest factors influencing vitamin C content of horticultural crops. Postharvest Biol Technol. 20:207-220.

Lima GPP, Brasil OG, Oliveira AM. 1999. Polyamines and peroxidase activity in bean (Phaseolus vulgaris L.) grown under saline stress. Sci Agric. 56:21-26.

Lima GPP, Lopes TDVC, Rossetto MRM, Vianello F. 2009. Nutritional composition, phenolic compounds, nitrate content in eatable vegetables obtained by conventional and certified organic grown culture subject to thermal treatment. Int J Food Sci Technol. 44:1118-1124.

Lima GPP, Vianello F. 2011. Review on the main differences between organic and conventional plant-based foods. Int J Food Sci Technol. 46:1-13.

Lundberg JO, Feelisch M, Björne H, Jansson EA, Weitzberg E. 2006. Cardioprotective effects of vegetables: Is nitrate the answer? Nitric Oxide. 15:359-362.

Müller K, Hippe J. 1987. Influence of differences in nutrition on important quality characteristics of some agricultural crops. Plant Soil. 100:35-45.

Popova M, Bankova V, Butovska D, Petkov V, Nikolova-Damyanova B, Sabatini AG, Marcazzan GL, Bogdanov S. 2004. Validated methods for the quantification of biologically active constituents of poplar-type propolis. Phytochem Anal. 15:235-240.

Pourcel L, Routaboul J, Cheynier V, Lepiniec L, Debeaujon I. 2006. Flavonoid oxidation in plants: from biochemical properties to physiological functions. Trends Plant Sci. 12:1360-1385.

Prachayasittikul S, Suphapong S, Worachartcheewan A, Lawung R, Ruchirawat S, Prachayasittikul V. 2009. Bioactive metabolites from Spilanthes acmella Murr. Molecules. 14:850-867.

Reif C, Arrigoni E, Neuweiler R, Baumgartner D, Nyström L, Hurrell RF. 2012. Effect of sulfur and nitrogen fertilization on the content of nutritionally relevant carotenoids in spinach (Spinacia oleracea). J Agric Food Chem. 60:5819-5824.

Siddhuraju P, Mohan PS, Beaker K. 2002. Studies on the antioxidant activity of Indian Laburnum (Cassia fistula L.): a preliminary assessment of crude extracts from stem bark, leaves, flowers and fruit pulp. Food Chem. 79:61-67.

Sims DA, Gamon JA. 2002. Relationships between leaf pigment content and spectral reflectance across a wide range of species, leaf structures and developmental stages. Remote Sens Environ. 81:337-354.

Singleton VL, Rossi JA. 1965. Colorimetric of total phenolics with phosphomolybdic-phosphotungstic acid reagents. Am J Enol Vitic. 16:144-158.

Smith-Spangler C, Brandeau ML, Hunter GE, Bavinger JC, Pearson M, Eschbach Sundaram V, Liu H, Schirmer P, Stave C, Olkin I, Bravata DM. 2012. Are organic foods safer or healthier than conventional alternatives? Ann Intern Med. 157:1-19.

Tiburcio AF, Kaur-Sawhney R, Galston AW. 1990. Polyamine metabolism. In: Miflin BJ, Lea PJ, editors. Intermediary nitrogen metabolism. New York (NY): Academic Press; p. 283-325. 
Toumi I, Gargouri M, Nouairi I, Moschou PN, Salem-Fnayou AB, Mliki A, Zarrouk M, Ghorbel A. 2008. Water stress induced changes in the leaf lipid composition of four grapevine genotypes with different drought tolerance. Biol Plant. 52:161-164.

Willer H, Lernoud J. 2013. Organic agriculture worldwide: key results from the FiBL-IFOAM survey on organic agriculture worldwide 2013. Slide collection. [Internet]. Frick: Research Institute of Organic Agriculture (FiBL); [cited 2013 Oct 23]. Available from: http://www.biofach.fibl.org/fileadmin/documents/de/biofach/2010/fibl-ifoam2010-world-of-organic-presentation-biofach.pdf

Winter CK, Davis SF. 2006. Organic foods. J Food Sci. 71:R117-R124.

Wongsawatkul O, Prachayasittikul S, Isarankura-Na-Ayudhya C, Satayavivad J, Ruchirawat S, Prachayasittikul V. 2008. Vasorelaxant and antioxidant activities of Spilanthes acmella Murr. Int J Mol Sci. 9:2724-2744.

Ximenes MIN, Rath S, Reyes FGR. 2000. Polarographic determination of nitrate in vegetables. Talanta. 51:49-56.

Zenebon O, Pascuet NS, Tiglea P. 2008. Physical and chemical methods for food analysis. 4th ed. [Internet]. São Paulo: Institute Adolfo Lutz; [cited 2013 Dec 20]. Available from: http://www.crq4.org.br/sms/files/file/ analisedealimentosial_2008.pdf [in Portuguese]. 